\title{
Strategies For Determining Sharia Insurance Target Market
}

\author{
Tiara Juliana Jaya ${ }^{1 *)}$, Yullina Devvie Sari ${ }^{2)}$, Roi Anju Immanuel ${ }^{3)}$ \\ ${ }^{1}$ Fakultas Ekonomi, Universitas Islam Negeri Maulana Malik Ibrahim Malang \\ ${ }^{2,3}$ PT. Bank Rakyat Indonesia, Tbk \\ *Corespondesi Email : tiarajulianajaya@uin-malang.ac.id
}

\begin{abstract}
The purpose of this research is to know the strategy of determining the target market in PRUlink Sharia assurance products pt. Prudential life assurance. The method used in this study is qualitatively descriptive. Descriptive statistical analysis techniques, stages of data analysis techniques Data collection, Data reduction data reduction, Presentation of data Presentation data, Withdrawal of conclusions. Strategy to determine the target market on PRUlink sharia assurance account products at PT. Prudential Life Assurance is: use the six o concept strategy so that the target market type. Types of target market selected, observation to the location, Muslim community, Grouping of insurance policy candidates, Ability factor by looking at a salary range of 2 million, and Prospective insurance policy that is at productive age for those between the ages of 25-40 years. PT. Prudential Live Assurance Metro branch should be able to continue to improve its Products so that it can continue to compete with PT. Insurances in Metro City and can give examples to other companies to use strategies implemented by PT. Prudential Live Assurance Metro branch, in order to reach the desired target market.
\end{abstract}

Keywords: Sharia Insurance, Market Share Strategies, Islamic Marketing, Target Market, Takaful

Citation suggestions: Jaya, T. J., Sari, Y. D., \& Immanuel, R. A. (2021). Strategies For Determining Sharia Insurance Target Market. Jurnal Ilmiah Ekonomi Islam, 7(01), 90-95. doi:http://dx.doi.org/10.29040/jiei.v7i1.1934

DOI: http://dx.doi.org/10.29040/jiei.v7i1.1934

\section{INTRODUCTION}

Often everyone in marketing has to change their marketing mix due to changes in the environment in which consumers live, work, and make purchasing decisions (Fachriza \& Moeliono, 2017). It should be that an organization designed a team of experts to continuously collect and evaluate environmental information, a process known as ecological scanning (Siagian, 2012). The purpose of environmental data collection is to identify future market opportunities and threats (Siagian, 2012). Market segmentation is a way to differentiate the market by buyer's class, user needs, motives, behaviors, and purchasing habits, how the product is used, and the purpose of purchasing the product. (Assauri, 2017) further explained that each group of consumers could be chosen as a target market to be achieved with different strategies, so it can also be obtained that market segmentation is a marketing strategy that is done consciously and deliberately to divide a market into parts, as a basis for fostering certain factors to be used as target markets to be served (Assauri, 2017).

Market segmentation is a two-step process that consists of naming the needs and segmenting these general markets to select the target market and carrying the appropriate marketing mix (E. Jerome McCarthy Dan William D. Perreault, 2011). Further segmentation of that market is the process of dividing a market into segments or groups that are meaningful, relatively similar, and identifiable (E. Jerome McCarthy Dan William D. Perreault, 2011). According to market segmentation is divided into several different buyer groups that may require other products or marketing mixes (Sucipto, 2011). Some of the things that sharia insurance agents can do to maintain the loyalty of the owner of the insurance policy are the first stage, do the planning, the second stage sees the prospects on each insurance policy owner, the third stage of the approach to finding the facts that exist, the fourth stage of the presentation 
related to the product, and the fifth stage is closing (Susilo \& Nikmah, 2018).

\section{a. Target Market}

Lamb, (2011) states that the market is People with organizations, Needs or desires, and Abilities and willingness to buy if a group of people or organizations that do not meet any of these four characteristics cannot be categorized as a market. According to (Assauri, 2017), the market is the market size of a product, the market scope of the product, the market structure, and the market share of the company's products, as well as the market space /opportunity of a product. In contrast to previous opinions, according to (E. Jerome McCarthy Dan William D. Perreault, 2011), the market is a group of potential customers who have the same needs who are willing to exchange something of value with the seller who offers a variety of goods or services that are a way to meet those needs. Further said by (E. Jerome McCarthy Dan William D. Perreault, 2011) the target market is a reasonably homogeneous (same) group of customers that the company will target.

The opinion was also approved by (Anoraga, 2009); according to him, the target market is a homogeneous group, which is the "target" of the company. According to (Lamb, 2011), the target market is a particular group that managers feel is most likely to buy the company's products. Based on some of the opinions mentioned above, according to the author of the target market is a group of potential consumers who want to be reached by the company in marketing its products so that the company must see the opportunities in deciding in order to get the market that has been targeted by the company. According to (Kotler \& Susanto, 1999), five target market selection patterns single Conciliation segment, Selective specialization, Product specialization, Market specialization, Market coverage.

Further explained (Assauri, 2017) to determine the target market in use of the concept of six O (The Six's O Concept) Who is in the market (Who is in the market), namely "Occupants," What does the market buy, namely: "Objects," When does the market buy, namely: "Occasions", Who is involved in the buying: "Organization," Why does the market buy: "Objectives," How does the market buy:
"Operation." Kotler \& Susanto (1999) Think the selection of target markets should be ethical because in goal setting, sometimes it raises opposition to its intent if the public becomes concerned if marketers take advantage of fragile groups (such as children) or groups that are based on unfavorable conditions. Whereas according to the strategy writer determining the target market, there are several that are what kind of market is being shot, who is in the market, what the market wants, why it is buying, then grouping it into segments.

b. Sharia Insurance

The definition of sharia insurance based on the National Sharia Council (DSN) and the Indonesian clerical assembly (MUI) is an effort to protect each other and help among many people through investments in assets and or tabarru' that provide a pattern of returns to deal with specific risks through sharia-compliant agreements. "Takaful insurance is a coverage that is in the form of help, or so-called kafal deeds, i.e., the act of helping each other in the face of a risk that was not foreseen (Lubis, 2000)." The principles of sharia insurance, according to Abdul Manan, are divided into three principles, namely Mutual responsibility, cooperation, Mutual protection from all suffering. (Rahman, 1995) insurance contract is only able to guarantee a certain amount of money to the person who enters insurance in the event of an accident.

c. Fund Management Mechanism

According to (Fadilah \& Makhrus, 2019) concerning the mechanism of fund management is classified into premiums with elements of savings and bonuses without the aspect of savings.

1) Premium with a savings element. In the case of premiums with this element of savings can be done in two ways:

- Savings account, i.e., a collection of funds that belong to participants paid when the agreement expires, participants withdraw, and participants die

- Special account, i.e., a collection of funds for which participants intend to donate to help each other and paid if the participant dies and the agreement expires if there is a surplus of funds. All funds raised from insurance participants' 
funds are invested following sharia principles. The proceeds obtained from the investment are distributed according to the income sharing system (almudahrabah), which is $60 \%$ for participants and $40 \%$ for the company.

2) Premium without savings element In a premium without this savings element, any compensation paid by the participant is put into a particular account. The fund is invested in sharia principles. Furthermore, the investment proceeds are included in the participant's fund pool, then reduced by insurance expenses (claims and insurance premiums). The surplus of the participant's fund is distributed following the income sharing system (al-mudharabah), a 40\% ratio for participants, and $60 \%$ in the provision for the company.

Also explained that sharia insurance takaful products are as follows (Lubis, 2000).

- Takaful hajj fund: This program is intended to prepare hajj funds for participants.

- Takaful plan: this is intended to prepare the funds as a provision for the day of participants as well as for the heirs.

- Takaful education: This takaful program is intended to prepare education funds for program participants' children.

- Takaful futures: i.e., programs intended for companies/institutions that want to prepare funds for employee/member heirs in the event of a deadly disaster.

- Takaful financing: this program is intended to guarantee the repayment of the remaining debt for those who have a loan in the event of a deadly disaster.

- Takaful health: this program is intended for families or companies that want to provide health funds for family members or their employees.

\section{METHOD AND DAYA ANALYSIS}

Researchers' research method is qualitative descriptive (Gunawan, 2013). The approach is done by observing directly on the instrument to obtain direct data and accurate results. Researchers in analyzing data using deskrifive statistical analysis techniques that are an analysis intended to explain the data of one variable that (Sanusi, 2011). Stages of data analysis techniques, namely:

a. Data collection at research sites by conducting observations, interviews, and documentation by determining data collection strategies that are seen as appropriate and relevant.

b. Data reduction Data reduction is a process of selection, focusing, randoming, transformation of rough data that exists in the field directly, and is passed on at the time of data collection, thus data reduction begins since researchers focused the research area.

c. Data presentation Data presentation is a set of information organizations that enable research to be conducted. The presentation of data is obtained of various types, networks of work, related activities or tables.

d. The draw of conclusions is that in data collection, researchers must understand and respond to something that is researched directly in the field by compiling a pattern of briefing patterns

\section{RESULTS AND DISCUSSION}

\subsection{Results}

\section{PRUlink Sharia Assurance Account}

PRUlink Sharia Assurance Account is a life insurance product that is associated with investments that provide protection and investment benefits following sharia principles. The requirement to become a policyholder is a minimum of 21 years, participants 1-70 years. According to Ernita as manager of PT. Prudential Life Assurance is one of the products in PT. Sharia-based Prudential Life Assurance, this product is most interested in insurance policies or insurance policies here. The main benefit of the PRUlink Sharia Assurance Account product is that it provides lifelong life protection to protect against total and permanent disability

PRUlink Sharia Assurance Account Product FeeTo be able to become a policy owner or participant only by paying the initial fee of Rp. $250.000,00$, and then the monthly deposit is at least Rp. 250.000,00. The provision of surplus sharing of $30 \%$ of surplus sharing will be held in tabarru', and the remaining $70 \%$ of surplus sharing will be distributed to participants and companies, With the following divisions:

- $0 \%$ is distributed to participants' policyholders; Dan

- $20 \%$ is the company's right as part of the profit. 
Surplus sharing is a fund that will be given to policyholders if there is an excess of funds from tabrru's account, including if there is other income after defunding claims and debts to the company if there is this surplus sharing at the end of the calendar year (January 1st to December 31st every year). It is then paid 30 April each year both to the company and to the participants.

\section{Sales Strategy}

Sales strategy at PT. Prudential Life Assurance has several stages (Susilo \& Nikmah, 2018), namely

a Planning the selling cycle phase begins with planning. An agent should have an excellent plan to start daily activities. Planning is a process that affects the current condition and the conditions that you want to achieve in the future. Planning can be done based on time, namely annual, monthly, weekly, daily.

b Prospecting the second stage is prospecting. Prospecting is the process of finding qualified people to buy prudential insurance products and will be our insurance policy. This can be done by grouping lead sources such as in a specific region, a particular city, a detailed organization, a typical family, or a particular person.

c Approaching is a process when you are trying to meet the people you are targeting. For example, by calling, we choose the right time at the time of getting so that the insurance policy feels comfortable and happy then promises to the prospective insurance policy. After the meeting, start with a talk about family, work, and others so that the forthcoming insurance policy feels comfortable. Only after that, we introduce the product PRUlink sharia assurance account.

$\mathrm{d}$ Presentation after the prospective insurance policy starts to be interested in ruling sharia assurance account products; then, the next stage is to explain if using insurance products.

e Handling delays in the sales process is not always acceptable and willing to insurance. Four delays occur, i.e., distrust, no need, no money, no rush. The way to deal with it is to stay calm, keep emotions, listen thoroughly, ask questions, offer solutions.

f Closing if the rejection can be handled properly, then do the closing or closing.

$\mathrm{g}$ Service in conducting services against prospective insurance policy PRUlink Sharia assurance account the company chooses in a qualified agent and willing to work hard.

\subsection{Discussion}

Sharia Prudential Insurance is life insurance that offers the advantages of investing and protection in accordance with sharia principles by being listed as one of the best and healthiest insurance. This can be seen from the rapid acquisition of insurance policy in just a few years. This is very interesting is how the strategy is used so that it gets a lot of insurance policies that are only within a few years and are Sharia-based insurance.

From the results of the study that the authors did in terms of strategies to determine the target market conducted by PT. Prudential Life Assurance on PRUlink Sharia Assurance Account products are as follows:

a The chosen target market type is the consumer market type, but when the market wants to turn into a manufacturer's market, it is a bonus for the company.

b By observing the location and looking for as much information as possible about the target market that will be shot from all sources.

c Targeting the Muslim community

d The grouping of prospective insurance policies of PT. Prudential Life Assurance to achieve the target market so that the strategy created is really about the target desired by the company.

e PT. Prudential Life Assurance determines its goals based on looking at the ability factor of prospective insurance policies with a salary range of 2 million because by looking at their purchasing power capabilities against the products they offer, it is the most important thing to see here the company targets people from the upper-middle class, not the other way around because it is considered to be less targeted if the company targets the target market from the lower middle class.

f Next PT. Prudential Life Assurance determines the target is also based on prulink Sharia Assurance Account products that want from all circles but especially in prospective insurance policies that are at productive age for those between 25-40 years old because at this age those who are actively working must have an insurance policy especially on the product PRUlink Syariah Assurance Account, if they get sick and die they have prepared the cost 
for treatment for themselves or if they die they have prepared in terms of finals for their families.

$\mathrm{g}$ In the strategy of determining the target market, there are two aspects that should be careful also namely profession and education, two aspects that are important and inseparable and affect the business development of PT. Prudential life assurance, more about the two aspects:

1) Profession

Because by knowing the profession, both employees, civil servants, and private employees can know the range of income and risks that may face it so that it can be known the limits of ability or purchasing power for the company.

2) Education

In the minimum education of high school, if people are low educated, they do not know how to manage the funds that are in sharia insurance and make them less interested and more listen to the opinions of people who are not necessarily the truth, thus making PT. Prudential Life Assurance selects them based on the education of prospective insurance policies because it is considered the candidate of insurance policy that has a higher education the better to understand the product PRUlink Sharia Assurance Account to be offered.

Based on the results of the research that the authors did can be known as the success strategy of PT. Prudential Life Assurance to achieve so many insurance policies in a fast period of time on PRUlink Sharia Assurance Account products.

\section{CONCLUSION}

Based on research and data assessment, it can be concluded that in the strategy of determining the target market on PRUlink sharia assurance account products at PT. Prudential Life Assurance is: use the concept strategy six O (The Six's O Concept) so that the target market type chosen thus is as follows,

1. The chosen target market type is the consumer market type, but when the market wants to turn into a manufacturer's market, it is a bonus for the company.

2. By observing the location and looking for as much information as possible about the target market that will be shot from all sources of the results of this study strengthens the previous research (Setiawan et al., 2018).
3. Muslim community, in line with the research that has been done before Sharia insurance products, will grow, along with the increase in the religion of participants. Thus, there is a potential development if sharia insurance is marketed to people who have a high level of righteousness (Ismanto, 2016).

4. The grouping of prospective insurance policies

5. Ability factor by looking at the salary range of 2 million.

6. Prospective insurance policies that are at productive age for those between the ages of 25-40 years

7. Two critical aspects interconnected, namely profession and education, because these two aspects are increasingly helpful in developing the PT business. Prudential Life Assurance

Because such a target market is a prospective insurance policy in the most appropriate PT value. Prudential Life Assurance to use PRUlink sharia assurance account products.

\section{ACKNOWLEDGMENT}

The authors thank all parties involved in the research strategies for determining Sharia Insurance Target Market both in data collection and interviews, especially to PT. Prudential Sharia.

\section{REFERENSI}

Anoraga, P. (2009). Manajemen Bisnis. Rineka Cipta. Assauri, S. (2017). Manajemen pemasaran: dasar, konsep \& strategi (15th ed.). Rajawali Perss.

E. Jerome McCarthy Dan William D. Perreault. (2011). Essentials Of Marketing A GlobalManagerial Approach (1st ed.). Binarupa Aksara.

Fachriza, F. I., \& Moeliono, N. (2017). Pengaruh Bauran Pemasaran Terhadap Keputusan Pembelian Rokok Mild. Jurnal Ecodemica: Jurnal Ekonomi, Manajemen, Dan Bisnis, 1(2), 139-148.

https://doi.org/10.31311/JECO.V1I2.1332

Fadilah, A., \& Makhrus, M. (2019). Pengelolaan Dana Tabarru' pada Asuransi Syariah dan Relasinya dengan Fatwa Dewan Syariah Nasional. Jurnal Hukum Ekonomi Syariah, 2(1), 87. https://doi.org/10.30595/jhes.v2i1.4416

Gunawan, I. (2013). Method of Qualitative Research Theory \& Pratik. PT Bumi Aksara. 
Jurnal Ilmiah Ekonomi Islam, 7(01), 2021, 95

Ismanto, K. (2016). Faktor-Faktor Yang Mempengaruhi Keputusan Pembelian Produk Asuransi Syariah di Pekalongan Kuat. Jurnal Hukum Islam (Journal of Islamic Law) - JHI, 14(1).

Kotler, P., \& Susanto, A. . (1999). Manajemen Pemasaran Di Indonesia. Salemba Empat.

Lamb, C. W. (2011). Marketing,Alih Bahasa:Thomson Learning, Pemasaran (11th ed.). Cegage Learning.

Lubis, S. K. (2000). Hukum Ekonomi Islam (1st ed.). Sinar Grafika.

Rahman, F. (1995). Doktrin Ekonomi Islam. PT. Dana Bhakti Wakaf.

Sanusi, A. (2011). Metodologi Penelitian Bisnis. Salemba Empat.
Setiawan, I. P., Manggabarani, A. S., \& Ilyas, J. B. (2018). Analisis Strategi Pemasaran Produk Asuransi Jiwa Berbasis Syariah Pada Industri Jasa Asuransi Di Kota Makassar (Studi Kasus Pada PT. Prudential Life Assurance Area Makassar). Management, 1(3).

Siagian, S. P. (2012). Manajemen Stratejik. Bumi Aksara.

Sucipto, A. (2011). Study Kelayakan Bisnis Analisis Integratif Dan Study Kasus. UIN-Maliki Press.

Susilo, E., \& Nikmah, M. (2018). Strategi Pemasaran Agen Asuransi Prulink Syariah Di Kabupaten Jepara. Ekonomika Syariah: Journal of Economic Studies, 2(2), 160-171. https://doi.org/http://dx.doi.org/10.30983/es.v2i2 .665 